\title{
Demam Tifoid pada Anak Usia di bawah 5 Tahun di Bagian Ilmu Kesehatan Anak RS Hasan Sadikin, Bandung
}

\author{
Djatnika Setiabudi dan Kiki Madiapermana
}

\begin{abstract}
Latar belakang: Di Indonesia demam tifoid bersifat endemik dan dari telaah kasus di beberapa rumah sakit, menunjukkan kecenderungan yang meningkat dari tahun ke tahun dengan rata-rata kesakitan 500/100.000 penduduk dan kematian 0,6-5,0 \%. Penelitian mengenai demam tifoid pada kelompok usia $<5$ tahun belum banyak dilaporkan.

Tujuan: mengetahui gambaran klinis dan laboratoris demam tifoid pada anak usia kurang dari 5 tahun dan membandingkan dengan anak usia di atas 5 tahun (5-14 tahun). Metoda: penelitian non-eksperimental bersifat retrospektif. Subjek penelitian adalah pasien demam tifoid anak dengan konfirmasi biakan Salmonella. Data diambil dari catatan rekam medik pasien demam tifoid yang dirawat di Bagian Ilmu Kesehatan Anak FK Unpad/RSHS Bandung dari bulan Januari 1996 sampai dengan Desember 2003.

Hasil: Selama kurun waktu 1996 - 2003 didapatkan kasus demam tifoid berusia < 5 tahun 108/256 (42,2\%). Dengan rasio laki-laki dan perempuan 1 : 1,20. Selain keluhan demam, obstipasi dan diare merupakan gejala yang paling sering ditemukan. Bradikardi relatif, hepatomegali dan lidah tifoid merupakan pemeriksaan yang sering ditemukan selain demam. Lebih dari setengah pasien didapatkan anemia dan trombositopenia. Komplikasi terjadi pada $25 \%$ kasus, yaitu gangguan neuropsikiatrik, sepsis dan syok septik, miokarditis dan ileus. Satu pasien meninggal dengan penyebab kematian syok septik.

Kesimpulan: insidens demam tifoid pada anak usia $<5$ tahun cukup tinggi, insides semakin tinggi sesuai dengan bertambahnya usia. Tidak ada perbedaan yang bermakna dalam gambaran klinis, laboratoris dan komplikasi pada demam tifoid kelompok anak berumur $<5$ tahun dibandingkan dengan anak umur $>5$ tahun.
\end{abstract}

Kata kunci: demam tifoid, balita, gambaran klinis, komplikasi

\footnotetext{
Alamat korespondensi:

Djatnika Setiabudi, dr., Sp.A

Bagian/SMF Ilmu Kesehatan Anak FKUP/RSUP dr. Hasan Sadikin

Jl. Pasteur No. 38 Bandung 40161

Telp./Fax. 2034426-203595
}

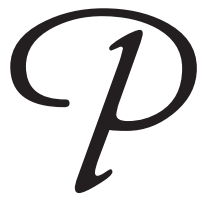

enyakit demam tifoid masih merupakan masalah kesehatan khususnya di negara sedang berkembang. Insidens demam tifoid masih tinggi meskipun komplikasi dan angka kematian sudah menurun dengan upaya diagnosis cepat dan pemberian antibiotik yang tepat. Pada tahun 2000 daerah yang termasuk mempunyai insidens tinggi demam tifoid (>100/100.000 kasus/tahun) adalah Asia Selatan, Tengah dan Tenggara. Daerah dengan insidens sedang (10- 
100/100.000 kasus/ tahun) adalah Asia bagian lainnya, Afrika, Amerika Latin dan Oceania kecuali Australia dan New Zealand; sedangkan daerah dengan insidens rendah yaitu $<$ 10/100.000 kasus/tahun adalah Amerika Utara, Eropa, dan negara maju lainnya. ${ }^{1}$ Di Indonesia demam tifoid bersifat endemik dan merupakan masalah kesehatan masyarakat. Dari telaah kasus di beberapa rumah sakit besar, kasus tersangka demam tifoid menunjukkan kecenderungan yang meningkat dari tahun ke tahun dengan rata-rata kesakitan 500/100.000 penduduk dengan kematian antara $0,6-5,0 \%{ }^{2}$

Berdasarkan data berbasis rumah sakit, demam tifoid lebih sering ditemukan pada kelompok usia sekolah dan dewasa muda. Insidens pada kelompok usia kurang dari 5 tahun umumnya rendah, meskipun ada suatu laporan berdasarkan studi komunitas insidensnya cukup tinggi mencapai $44 \%{ }^{3}$

Gambaran klinis demam tifoid sangat bervariasi, ringan sampai berat dengan komplikasi yang dapat menyebabkan kematian. Salah satu faktor yang mempengaruhi variasi ini terutama adalah usia. ${ }^{4}$ Meskipun demam tifoid pada usia $<5$ tahun dapat disertai sepsis, secara umum gambaran klinis lebih ringan sehingga dapat menyulitkan dalam menegakkan diagnosis. Penelitian mengenai demam tifoid pada kelompok usia $<5$ tahun belum banyak dilaporkan (khususnya) di Indonesia.

Tujuan penelitian untuk mengetahui gambaran klinis dan laboratoris demam tifoid pada anak usia kurang dari 5 tahun dan membandingkannya dengan anak usia 5-14 tahun.

\section{Bahan dan Cara}

Penelitian ini merupakan penelitian non-eksperimental, retrospektif. Subjek penelitian adalah pasien demam tifoid anak dengan usia $<5$ tahun. Sebagai kontrol pasien demam tifoid usia 5-14 tahun. Data diambil dari catatan rekam medik kasus demam tifoid yang dirawat di Bagian Ilmu Kesehatan Anak FK Unpad/RSHS Bandung dari bulan Januari 1996 sampai dengan Desember 2003. Data yang dikumpulkan meliputi usia, jenis kelamin, gambaran klinis dan laboratoris serta komplikasi. Subjek penelitian ini juga telah digunakan dalam penelitian lain dengan judul "Prediktor terjadinya demam tifoid berat pada anak". ${ }^{5}$

Demam tifoid adalah pasien yang memperlihatkan manifestasi klinis dan laboratoris yang mengarah ke diagnosis demam tifoid dengan konfirmasi hasil biakan positif untuk kuman Salmonella typhi.

Status gizi ditentukan dari hasil pengukuran antropometri berat badan terhadap tinggi badan $(\mathrm{BB} /$ $\mathrm{TB})$ dan/atau berat badan terhadap usia $(\mathrm{BB} / \mathrm{U})$ yang dibandingkan dengan Tabel standar dari NCHS. Pasien dikelompokkan menjadi kelompok gizi kurang $(\mathrm{BB} / \mathrm{TB}<90 \%$ dan/atau $\mathrm{BB} / \mathrm{U}<80 \%)$; gizi baik $(\mathrm{BB} /$ TB 90-120\% dan/atau BB/U 80-110\%) dan gizi lebih $(\mathrm{BB} / \mathrm{TB}>120 \%$ dan/atau $\mathrm{BB} / \mathrm{U}>110 \%){ }^{6}$

Anemia didefinisikan berdasarkan kriteria WHO yaitu usia 6 bulan -5 tahun bila kadar Hb kurang dari $11 \mathrm{~g} / \mathrm{dl}$, usia 6 - 12 tahun kadar Hb kurang dari 11,5 $\mathrm{g} / \mathrm{dl}$ dan usia $>12$ tahun kadar Hb kurang dari $12 \mathrm{~g} / \mathrm{dl}$.

Leukopenia apabila hitung jumlah leukosit darah di bawah nilai normal batas bawah, sedangkan leukositosis apabila hitung jumlah leukosit di atas normal batas atas untuk usia yang sesuai. ${ }^{7}$ Limfositosis relatif didefinisikan apabila persentase limfosit dari hasil hitung jenis leukosit lebih besar dari nilai normal sesuai usia, sedangkan jumlah leukosit total normal atau leukopenia.

Trombositopenia apabila hitung jumlah trombosit kurang dari $150.000 / \mathrm{mm}^{3} .{ }^{8}$ Hasil laboratorium dicatat dan diikutkan dalam analisis berdasarkan pemeriksaan pada saat pertama kali masuk dirawat.

Komplikasi demam tifoid dikelompokkan adalah komplikasi neuropsikiatrik; gastrointestinal (perdarahan dan perforasi usus); sepsis dan syok sepsis; kelainan hematologik seperti anemia hemolitik dan koagulopati intravaskular diseminata (KID); kelainan jantung seperti miokarditis dan endokarditis; serta infeksi lain seperti meningitis, pneumonia, hepatitis, nefritis, kolesistitis, artritis septik dan sebagainya. Komplikasi dapat terjadi baik pada saat pertama dirawat atau terjadi selama perawatan. Komplikasi yang secara nyata ditimbulkan oleh sebab lain seperti alergi obat dan akibat prosedur tindakan yang diberikan tidak dicatat sebagai komplikasi demam tifoid.

Data dicatat dan selanjutnya dianalisis menggunakan program komputer SPSS versi 11. Untuk membandingkan beberapa variabel data kategori pada pasien usia $<5$ tahun dengan $>5$ tahun digunakan uji chi-kuadrat atau Fisher's exact.

\section{Hasil}

Selama kurun waktu 1996 - 2003 didapatkan 256 kasus demam tifoid dengan konfirmasi hasil biakan Salmonella 
typhi positif, 108 diantaranya $(42,2 \%)$ berusia $<5$ tahun. Berdasarkan tahun perawatan, jumlah kasus tertinggi yang dirawat pada tahun 1997 (19 orang) dan terendah pada tahun 2003 (10 orang). Persentase kelompok < 5 tahun berkisar antara 33,3-48,0\% (Tabel 1).

Berdasarkan jenis kelamin, laki-laki berbanding perempuan masing-masing 49 dan 59 orang (rasio 1 : 1,20). Dari 108 kasus usia < 5 tahun, sebagian besar (90,74\%) berada dalam kelompok usia $2-5$ tahun sedangkan sisanya 10 orang $(9,26 \%)$ berusia $<2$ tahun. Insidens semakin bertambah sesuai dengan bertambahnya usia pasien (Tabel 2).

Berdasarkan status gizi, sebagian besar pasien mempunyai gizi kurang $(50,9 \%)$ dan gizi baik $(47,2 \%)$. Gizi buruk dan gizi lebih masing-masing ditemukan pada 1 pasien $(1,4 \%)$.

Keluhan utama yang paling sering adalah demam $94,4 \%$, sedangkan keluhan utama lainnya berupa kejang 2 orang $(1,9 \%)$ serta penurunan kesadaran, buang air besar berdarah, nyeri seluruh perut dan perut kembung masing-masing 1 orang $(0,9 \%)$. Lama demam di rumah bervariasi dari 1 - 30 hari dengan rata-rata 8,68 hari ( median 8,0 hari dan modus 7,0 hari). Lama demam antara $7-14$ hari merupakan yang paling sering dikeluhkan $(77,8 \%)$, selanjutnya demam $<7$ hari $(17,6 \%)$ serta antara 14-21 hari dan $>21$ hari masingmasing sebesar 2,8 dan 1,9\%. Selain keluhan demam, gangguan saluran pencernaan berupa obstipasi dan diare merupakan gejala yang sering ditemukan, yaitu masingmasing sebesar 42,6 dan 40,7\%. Gejala atau keluhan lain selengkapnya dan perbandingan dengan kelompok usia $>5$ tahun tertera pada Tabel 3 .

Suhu pada saat masuk dirawat berkisar antara 36,0 $-40,9^{\circ} \mathrm{C}$, dengan rata-rata $38,7^{\circ} \mathrm{C}$ (median $38,9^{\circ} \mathrm{C}$ ). Selain demam gejala klinis pada saat masuk dirawat yang sering ditemukan adalah bradikardi relatif $(28,7 \%)$, hepatomegali $(20,4 \%)$ dan lidah tifoid $(13,0 \%)$. Data selengkapnya tertera pada Tabel 4.

Pada hasil pemeriksaan laboratorium darah saat penderita masuk dirawat lebih dari setengahnya didapatkan anemia $(58,3 \%)$, jumlah leukosit normal $(52,8 \%)$ dan trombositopenia $(55,6 \%)$. Limfositosis relatif didapatkan pada 28,6\% kasus (Tabel 5).

Dari 108 kasus< 5 tahun, 27 (25\%) mengalami komplikasi sedangkan pada kelompok $>5$ tahun sebanyak 31,1\% ( $\mathrm{p}=0,287)$. Komplikasi yang sering terjadi pada kelompok $<5$ tahun yaitu gangguan neuropsikiatrik $(12,0 \%)$ berupa ensefalopati, delirium

Tabel 1. Distribusi jumlah kasus demam tifoid berdasarkan tahun perawatan

\begin{tabular}{llllllll}
\hline Tahun & \multicolumn{2}{c}{ Umur $<5$ tahun } & \multicolumn{2}{c}{ 5-9 tahun } & \multicolumn{2}{c}{$10-14$ tahun } & Jumlah \\
\cline { 2 - 6 } Perawatan & $\mathrm{n}$ & $(\%)$ & $\mathrm{n}$ & $(\%)$ & $\mathrm{n}$ & $(\%)$ & \\
\hline 1996 & 13 & $(44,8)$ & 10 & $(34,5)$ & 6 & $(20,7)$ & 29 \\
1997 & 19 & $(44,2)$ & 11 & $(30,2)$ & 11 & $(25,6)$ & 43 \\
1998 & 12 & $(46,2)$ & 10 & $(38,5)$ & 4 & $(15,4)$ & 26 \\
1999 & 12 & $(48,0)$ & 8 & $(32,0)$ & 5 & $(20,0)$ & 25 \\
2000 & 12 & $(38,7)$ & 11 & $(35,5)$ & 8 & $(25,8)$ & 31 \\
2001 & 12 & $(38,7)$ & 13 & $(41,9)$ & 6 & $(19,4)$ & 31 \\
2002 & 18 & $(43,9)$ & 17 & $(41,5)$ & 6 & $(14,6)$ & 41 \\
2003 & 10 & $(33,3)$ & 15 & $(50,0)$ & 5 & $(16,7)$ & 30 \\
\hline Jumlah & 108 & $(42,2)$ & 97 & $(37,9)$ & 51 & $(19,9)$ & 256 \\
\hline
\end{tabular}

Tabel 2. Distribusi berdasarkan kelompok usia dan jenis kelamin

\begin{tabular}{ccccc}
\hline Usia (tahun) & Laki-laki & Perempuan & Jumlah & $(\%)$ \\
\hline $0-1$ & 1 & 0 & 1 & $(0,9)$ \\
$>1-2$ & 5 & 4 & 9 & $(8,3)$ \\
$>2-3$ & 13 & 14 & 27 & $(25,0)$ \\
$>3-4$ & 12 & 18 & 30 & $(27,8)$ \\
$>4-5$ & 18 & 23 & 41 & $(38,0)$ \\
\hline Jumlah & 49 & 59 & 108 & $(100)$ \\
\hline
\end{tabular}

dan ansietas. Komplikasi berikutnya adalah sepsis dan syok septik $(6,5 \%)$, miokarditis $(2,8 \%)$, ileus $(2,8 \%)$. Data selengkapnya tertera pada Tabel 6.

Lama perawatan di rumah sakit berkisar antara 4 25 hari dengan rata-rata 10,9 hari (median 10 hari). Pada kelompok usia 5 - 14 tahun lama perawatan antara 2 - 22 hari (rata-rata 11,1 hari, median 10,8 hari).

Angka kematian pada pasien usia $<5$ dan $5-14$ tahun ditemukan masing-masing 1 pasien $(0,9 \%$ dan $0,7 \%)$ dengan penyebab kematian yang sama yaitu syok septik. 
Tabel 3. Tanda dan gejala klinis saat masuk dirawat

\begin{tabular}{|c|c|c|c|c|}
\hline \multirow{2}{*}{$\begin{array}{l}\text { Keluhan/ } \\
\text { Gejala }\end{array}$} & \multicolumn{3}{|c|}{ Umur $<5$ tahun $5-14$ tahun } & \multirow{2}{*}{$\mathrm{p}$} \\
\hline & n $\quad(\%)$ & $\mathrm{n}$ & $(\%)$ & \\
\hline Obstipasi & $46(42,6)$ & 58 & $(39,2)$ & 0,584 \\
\hline Diare & $44(40,7)$ & 61 & $(41,2)$ & 0,939 \\
\hline Anoreksia & $40(37,4)$ & 56 & $(37,8)$ & 0,537 \\
\hline Mual/muntah & $35(32,4)$ & 60 & $(40,5)$ & 0,183 \\
\hline Batuk & $30(27,8)$ & 4 & $(28,4)$ & 0,916 \\
\hline Nyeri kepala & $19(17,6)$ & 56 & $(37,8)$ & 0,001 \\
\hline Nyeri perut & $17(15,9)$ & 33 & $(22,3)$ & 0,203 \\
\hline Mengigau & $10(9,3)$ & 22 & $(14,9)$ & 0,180 \\
\hline Penuruna kesadaran & $5(4,6)$ & 11 & $(7,4)$ & 0,360 \\
\hline Kejang & $2(1,9)$ & - & & \\
\hline Perut kembung & $1 \quad(0,9)$ & 2 & $(1,4)$ & 1,000 \\
\hline
\end{tabular}

Tabel 4. Pemeriksaan fisik saat masuk dirawat

\begin{tabular}{|c|c|c|c|c|}
\hline \multirow[t]{2}{*}{ Pemeriksaan Fisik } & \multicolumn{3}{|c|}{$0-5$ tahun $5-14$ tahun } & \multirow{2}{*}{$\mathrm{p}$} \\
\hline & $\mathrm{n} \quad(\%)$ & $\mathrm{n}$ & $(\%)$ & \\
\hline \multicolumn{5}{|l|}{ Kesan sakit } \\
\hline Ringan & $3(2,8)$ & 6 & $(4,1)$ & 0.374 \\
\hline Sedang & $4(87,0)$ & 119 & $(80,4)$ & \\
\hline Berat & $11(10,2)$ & 23 & $(15,5)$ & \\
\hline \multicolumn{5}{|l|}{ Kesadaran } \\
\hline Kompos mentis & $99(91,7)$ & 130 & $(87,8)$ & 0,598 \\
\hline Obtundasi/apatis & $2(1,9)$ & 4 & $(2,7)$ & \\
\hline Somnolen/letargis & $6(5,6)$ & 8 & $(5,4)$ & \\
\hline Delirium & $1 \quad(0,9)$ & 6 & $(4,1)$ & \\
\hline Bradikardi relatif & $31(28,7)$ & 57 & $(38,5)$ & 0,103 \\
\hline Hepatomegali & $22(20,4)$ & 32 & $(21,6)$ & 0,809 \\
\hline Lidah tifoid & $14(13,0)$ & 30 & $(20,3)$ & 0,126 \\
\hline Splenomegali & $1 \quad(0,9)$ & 1 & $(0,7)$ & 0,822 \\
\hline Rose spot & - & 2 & $(1,4)$ & \\
\hline
\end{tabular}

\section{Diskusi}

Masalah yang sering menjadi pertanyaan adalah berapa insidens demam tifoid pada kelompok usia < 5 tahun? Apakah gambaran klinis dan komplikasi pada kelompok $<5$ tahun lebih berat atau sebaliknya dibandingkan dengan usia lebih tua atau dewasa?

Pada penelitian ini didapatkan insidens demam tifoid pada usia $<5$ tahun sebesar $42,2 \%$. Hasil ini lebih besar bila dibandingkan dengan insidens periode sebelumnya di rumah sakit yang sama yaitu sebesar $28 \% .{ }^{9}$ Hasil ini juga sangat berbeda dengan salah satu penelitian di India (1981-1987) 13,5\%. ${ }^{10}$ Mahle dan Levine (1993) dalam laporannya berdasarkan data
Tabel 5. Hasil pemeriksaan laboratorium saat masuk

\begin{tabular}{|c|c|c|c|c|}
\hline \multirow{2}{*}{$\begin{array}{l}\text { Pemeriksaan } \\
\text { Laboratorium }\end{array}$} & \multicolumn{3}{|c|}{ 0-5 tahun 5-14 tahun } & \multirow[t]{2}{*}{$\mathrm{p}$} \\
\hline & $\mathrm{n} \quad(\%)$ & $\mathrm{n}$ & $(\%)$ & \\
\hline $\begin{array}{l}\text { Anemia } \\
\qquad\left(\mathrm{n}_{1}=108\right),\left(\mathrm{n}_{2}=148\right) \\
\text { Jumlah leukosit**: } \\
\quad\left(\mathrm{n}_{1}=106\right),\left(\mathrm{n}_{2}=144\right)\end{array}$ & $63(58,3)$ & 82 & $(55,4)$ & 0,641 \\
\hline Leukopenia & $48(45,3)$ & 78 & $(54,2)$ & 0,174 \\
\hline Normal & $56(52,8)$ & 64 & $(44,4)$ & \\
\hline Leukositosis & $2(1,9)$ & 2 & $(1,4)$ & \\
\hline $\begin{array}{l}\text { Limfositosis relatif } \\
\qquad\left(\mathrm{n}_{1}=49\right),\left(\mathrm{n}_{2}=83\right)\end{array}$ & $14(28,6)$ & 28 & $(33,7)$ & 0,387 \\
\hline $\begin{array}{l}\text { Trombositopenia } \\
\qquad\left(\mathrm{n}_{1}=54\right),\left(\mathrm{n}_{2}=89\right)\end{array}$ & $30(55,6)$ & 40 & $(44,9)$ & 0,242 \\
\hline $\begin{array}{r}\text { Keterangan : } \\
{ }^{*} \text { tidak semu } \\
\mathrm{n}_{1}=\text { jumlah } \\
\mathrm{n}_{2}=\text { jumlah } \\
\\
{ }^{* *} \text { leukosito }\end{array}$ & $\begin{array}{l}\text { penderita dip } \\
\text { pasien } 0-5 \text { tah } \\
\text { pasien } 5-14 \text { tah } \\
\text { is tidak diikutk }\end{array}$ & iksa se & cara lengk & \\
\hline
\end{tabular}

Tabel 6. Jumlah pasien yang mengalami komplikasi

\begin{tabular}{lcc}
\hline Komplikasi* $\left.^{*} \mathrm{n}=108\right)$ & Jumlah & Persentase \\
\hline Gangguan neuropsikiatrik & 13 & 12,0 \\
Sepsis dan syok septik & 7 & 6,5 \\
Miokarditis & 3 & 2,8 \\
Ileus paralitik & 3 & 2,8 \\
Hepatitis & 2 & 1,9 \\
Kejang demam & 2 & 1,9 \\
Kolesistitis & 1 & 0,9 \\
Perdarahan usus & 1 & 0,9 \\
\hline
\end{tabular}

Keterangan : * seorang pasien dapat mempunyai lebih dari satu komplikasi

berbasis rumah sakit mendapatkan kesimpulan bahwa insidens demam tifoid pada anak $<5$ tahun sangat bervariasi berkisar antara $11-46 \%$, meskipun sebagian besar menunjukkan insidens yang jauh lebih kecil dibandingkan usia yang lebih tua. Salah satu penelitian prospektif berbasis komunitas di daerah urban di India mendapatkan insidens demam tifoid pada anak $<5$ tahun sebesar $44 \%,{ }^{3}$ hal ini tidak jauh berbeda dengan hasil penelitian ini $(42,2 \%)$. Brooks dkk $(2005)^{12}$ dalam penelitiannya di daerah urban slum di Dhaka dengan surveilans aktif mendapatkan besarnya risiko relatif anak pra-sekolah untuk mendapat penyakit demam tifoid sebesar 8,9 kali dibandingkan dengan kelompok usia yang lebih tua. Insidens demam tifoid pada kelompok 
usia $<3$ tahun pada penelitian ini 34,26\%, tidak jauh berbeda dengan hasil penelitian Rajajee dkk (1995) di India 39\%. Pada penelitian tersebut didapatkan bahwa hanya $49-52 \%$ saja isolat Salmonella typhi yang sensitif terhadap kloramfenikol, ampisilin dan kotrimoksazol. ${ }^{13}$ Perbedaan insidens yang sangat besar ini kemungkinan disebabkan oleh periode (waktu) penelitian, desain penelitian retro atau prospektif, endemisitas daerah penelitian, tingkat resistensi kuman Salmonella typhi dan apakah penelitian berbasis rumah sakit atau komunitas.

Gejala /keluhan pada penelitian ini pasien demam tifoid usia $<5$ tahun meskipun banyak perbedaan dengan usia $>5$ tahun, namun tidak berbeda bermakna kecuali keluhan nyeri kepala. Oleh karena pada kelompok anak yang lebih kecil akan mengalami kesulitan dalam mengungkapkan keluhan nyeri kepala. Kejadian keluhan obstipasi lebih besar daripada diare (42,6\% vs $40,7 \%)$, berbeda dengan hasil penelitian Setiabudi dkk, ${ }^{9}$ yang melaporkan frekuensi diare lebih sering ditemukan pada anak $<5$ tahun dibandingkan dengan obstipasi. Stephen dan Levine (2002) ${ }^{14}$ juga mengemukakan bahwa obstipasi lebih sering ditemukan pada anak yang lebih tua dan dewasa, sedangkan diare (green pea-soup like stool) lebih sering pada usia lebih muda. ${ }^{14}$

Dari pemeriksaan fisik umumnya tidak ada perbedaan yang bermakna antara anak $<5$ tahun dengan anak $>5$ tahun. Hasil ini sesuai dengan penelitian Sinha dkk, bahwa morbiditas pada anak < 5 tahun serupa dalam hal lamanya demam, gejala dan hasil pemeriksaan fisik. ${ }^{3}$ Meskipun demikian pada anak $<5$ tahun memperlihatkan kejadian yang lebih kecil dalam pemeriksaan fisik seperti bradikardi relatif, lidah tifoid, dan hepatomegali. Bradikardi relatif yang sebelumnya jarang ditemukan atau tidak diperiksa ternyata merupakan yang paling banyak ditemukan $(28,7 \%)$. Hepatomegali dan splenomegali ditemukan sebesar 20,4 dan $0,9 \%$, berbeda dengan hasil penelitian sebelumnya di rumah sakit yang sama. Azhali dan Garna (1987) mendapatkan angka masing-masing sebesar 51,4 dan 1,0\%; ${ }^{15}$ Wahyunarti (1989) mendapatkan 91,2 dan 8,8\%; ${ }^{16}$ Pasaribu (1992) mendapatkan 78,0 dan 35,0\% ${ }^{17}$ dan Setiabudi (1997) mendapatkan 48,0 dan 4,0\%. ${ }^{9}$ Keempat penelitian terdahulu mencakup semua usia 0 - 14 tahun, dengan kejadian yang lebih tinggi dari penelitian ini. Apakah faktor usia berperan dalam perbedaan ini perlu diteliti lebih lanjut. Wahyunarti dan Pasaribu melakukan penelitian prospektif sedangkan penelitian ini, Azhali dan Setiabudi secara retrospektif.
Hal ini juga mungkin menjadi salah satu penyebab variasi yang sangat besar. Pada penelitian ini anemia dan trombositopenia lebih besar kejadiannya pada anak $<5$ tahun dibandingkan pada anak $>5$ tahun, sedangkan leukopenia lebih kecil meskipun perbedaan tidak bermakna. Hasil ini berbeda dengan penelitian Setiabudi, yang mendapatkan leukopenia lebih sering pada anak $<5$ tahun. ${ }^{9}$

Komplikasi pada anak $<5$ tahun lebih kecil kejadiannya dibandingkan dengan anak $>5$ tahun $(25,0 \%$ dan $31,1 \%)$, meskipun tidak berbeda bermakna. Komplikasi yang sering pada anak $<5$ tahun adalah gangguan neuropsikiatrik (paling banyak adalah ensefalopati), sepsis dan syok septik, miokarditis dan ileus paralitik. Pandey dkk mengemukakan hal serupa yaitu syok endotoksik dan ensefalopati merupakan komplikasi paling sering pada anak $<5$ tahun. ${ }^{10}$ Malik (2002) mengemukakan bahwa komplikasi tidak berhubungan dengan usia. ${ }^{18}$ Madiapermana (2004), juga mengemukakan bahwa usia $<5$ tahun bukan merupakan prediktor untuk terjadinya demam tifoid berat. ${ }^{5}$ Hal yang berbeda dikemukakan oleh Butler dan Bhutta bahwa usia pasien khususnya bayi mempengaruhi komplikasi dan kematian. ${ }^{19,20}$

\section{Kesimpulan}

Insidens demam tifoid pada anak usia $<5$ tahun cukup tinggi, sesuai dengan bertambahnya usia. Tidak ada perbedaan dalam hal gambaran klinis, laboratoris dan komplikasi pada demam tifoid anak $<5$ tahun dibandingkan dengan anak $>5$ tahun.

\section{Daftar Pustaka}

1. Crump JA, Luby SP, Mintz ED. The global burden of typhoid fever. Bull World Health Organ 2004;82:346-53.

2. Direktorat Jendral PPM \& PL, Departemen Kesehatan Indonesia. Pedoman pengendalian demam tifoid bagi tenaga kesehatan. Jakarta, 2003.

3. Sinha A, Sazawal S, Kumar R. Typhoid fever in children aged less than 5 years. Lancet 1999;354:734-7.

4. Cleary TG. Salmonella. Dalam: Behrman RE, Kliegman RM, Jenson HB, penyunting. Nelson Textbook of Pediatrics. Edisi ke-17. Philadelpia: Saunders; 2004. h. 912-9.

5. Madiapermana K. Prediktor terjadinya demam tifoid berat pada anak. Tesis Bagian Ilmu Kesehatan Anak FK 
UNPAD. Bandung: Fakultas Kedokteran Universitas Padjadjaran, 2004.

6. World Health Organization. Physical status: the use and interpretation of anthropometry. Report of a WHO expert committee 1995, Geneva.

7. Nathan DG, Orkin SH, penyunting. Nathan and Oski’s hematology of infancy and childhood. Edisi ke-5. Philadelphia : Saunders; 1998 (appendix 28).

8. Montgomery RR, Scott JP. Hemorrhagic and thrombotic diseases: platelet and blood vessel disorder. Dalam: Behrman RE, Kliegman RM, Jenson HB, penyunting. Nelson Textbook of Pediatrics. Edisi ke-17. Philadelpia: Saunders; 2004.h.1670-4.

9. Setiabudi D, Azhali, Garna H, Chairulfatah A. Clinical and laboratory features of pediatric typhoid fever at the Department of Child Health, Hasan Sadikin Hospital Bandung. Dipresentasikan pada $3^{\text {rd }}$ Asia-Pasific Symposium on Typhoid Fever and Other Salmonellosis; 1997 Dec 8-10. Bali, Indonesia.

10. Pandey KK, Srinivasan S, Mahadevan S, Nalini P, Rao RS. Typhoid fever below five years. Indian Pediatr 1990;27:153-6.

11. Mahle WT, Levine MM. Salmonella typhi infection in children younger than five years of age. Pediatr Infect Dis J 1993;12:627-31.

12. Brooks WA, Hossain A, Goswami D, dkk. Bacteremic typhoid fever in children in an urban slum, Bangladesh.
Emerg Infect Dis 2005;11:326-9.

13. Rajajee S, Anandi TB, Subha S, Vatsala BR. Patterns of resistant Salmonella typhi infection in infants. J Trop Pediatr 1995;41:52-4.

14. Stephens I, Levine MM. Management of Typhoid fever in children. Pediatr Infect Dis J 2002;21:157-9.

15. Azhali , Garna H. Gambaran klinis penyakit tifus abdominalis pada anak. MKB (Majalah Kedokteran Bandung) 1987;20:5-9.

16. Wahyunarti R. Nilai diagnostik tes Widal pada anakanak dengan tifus abdominalis di RSU dr Hasan sadikin Bandung. Tesis Bagian Ilmu Kesehatan Anak FK UNPAD. Bandung: Fakultas Kedokteran Universitas Padjadjaran, 1989.

17. Pasaribu A. Nilai diagnostik pemeriksaan Widal pada anak dengan demam tifoid di RSU dr. Hasan Sadikin Bandung. Tesis Bagian Ilmu Kesehatan Anak FK UNPAD. Bandung: Fakultas Kedokteran Universitas Padjadjaran, 1992.

18. Malik AS. Complications of bacteriologically confirmed typhoid fever in children. J Trop Pediatr 2002;48:102-8.

19. Butler T, Islam A, Kabir I, Jones PK. Patterns of morbidity and mortality in typhoid fever dependent on age and gender: review of 552 hospitalized patients with diarrhea. Rev Infect Dis 1991;13:85-90.

20. Bhutta ZA. Impact of age and drug resistance on mortality in typhoid fever.Arch Dis Child 1996;75:214-7. 